\title{
EFFECT OF MACHINING PARAMETERS ON SURFACE ROUGHNESS, POWER CONSUMPTION, AND MATERIAL REMOVAL RATE OF ALUMINIUM 6065-SI-MWCNT METAL MATRIX COMPOSITE IN TURNING OPERATIONS
}

\author{
Savina Jaddinagadhe Puttaswamy* and \\ Raghavendra Bommanahalli Venkatagiriyappa \\ Department of Mechanical Engineering, JSS Academy of Technical Education, \\ Bangalore-560060, India \\ "Corresponding author: mailtosavin@gmail.com
}

(Received: $4^{\text {th }}$ October 2020; Accepted: $25^{\text {th }}$ March 2021; Published on-line: $4^{\text {th }}$ July 2021)

\begin{abstract}
Nanocomposites were prepared with Al-6065-Si and multi walled carbon nanotubes of 1 wt.\% as reinforcement through the stir-casting method. Fabricated nanocomposites were machined on a lathe machine using a tungsten carbide tool. The study investigated the multi-objective optimization of the turning operation. Cutting velocity, feed, and depth of cut were considered for providing minimum Surface Roughness of the workpiece. Also, the power consumed by the lathe machine with maximum metal removal rate was examined by surface response methodology. The design of experiments was developed based on rotational central composite design. Analysis of variance was executed to investigate the adequacy and the suitable fit of the developed mathematical models. Multiple regression models were used to represent the relationship between the input and the desired output variables. The analysis indicates that the feed is the most influential factor that effects the surface roughness of the workpiece. Cutting speed and the depth of cut are two other important factors that proportionally influence the power consumed by the lathe tool as compared to the feed rate.
\end{abstract}

ABSTRAK: Komposit nano disediakan bersama Al-6065-Si dan karbon nanotiub berbilang dinding sebanyak 1 wt.\% sebagai bahan penguat melalui kaedah kacauantuangan. Komposit nano yang terhasil melalui mesin pelarik ini menggunakan alat tungsten karbida. Kajian ini merupakan pengoptimuman pelbagai objektif operasi pusingan. Kelajuan potongan, suapan dan kedalaman potongan diambil kira sebagai pemberian minimum pada kekasaran permukaan bahan kerja. Tenaga yang digunakan bagi mesin pelarik dengan kadar maksimum penyingkiran logam diteliti melalui kaedah tindak balas permukaan. Rekaan eksperimen yang dibangunkan ini adalah berdasarkan rekaan komposit pusingan tengah. Analisis varian telah dijalankan bagi mengkaji kecukupan dan penyesuaian lengkap bagi model matematik yang dibangunkan. Model regresi berganda digunakan bagi menunjukkan hubungan antara input dan pembolehubah output yang dikehendaki. Analisis menunjukkan pemberian suapan merupakan faktor mempengaruhi keberkesanan kekasaran permukaan bahan kerja. Kelajuan pemotongan dan kedalaman potongan adalah dua faktor penting lain yang mempengaruhi kadar langsung ke atas tenaga yang digunakan oleh mesin pelarik dibandingkan kadar pemberian suapan.

KEYWORDS: MWCNT (multi-walled carbon nanotube); power consumption; machining; cutting force; central composite design; response surface methodology 


\section{INTRODUCTION}

Carbon-nanotubes reinforced with AMMC's in the recent technological era are gaining high importance among various classes of composites. Researchers have made attempts to produce MMCs with CNT as reinforcement material. Core research on metals such as aluminum and aluminum alloy materials [1,2], due to their light weight, high strength composites, are sought for dynamic mechanical systems like aerospace industries, robotics and automobiles [3]. Materials with high stiffness, modulus, strength, low density, and high specific surface are associated in carbon nanotubes as an ideal reinforcement [4].

The presence of hard MWCNT reinforcement and its abrasive nature affects the quality of the workpiece resulting in difficulty of machining and wear of the cutting tool [5]. The traditional machining process, if adopted in composite materials with appropriate tool design and the optimal operating conditions can resolve this difficulty. These raw materials are very expensive. In order to reduce their wastage during the final conversion of the composites into engineering products and to obtain the required geometrical parts, it becomes necessary to investigate and study the basic manufacturing and machinability of the material at the time of design of material and selection [6,7]. The machining of composites depends mainly on their various reinforcements and diverse matrix properties. The cutting tool will be alternatively in contact with the base metal and the reinforcing materials and hence the response obtained by the machining of composite materials can be completely different. Thus, the cutting tool's material, geometry, and wear resistance play critical roles for the machining of composite materials. Correspondingly, the different machine operating parameters like the feed, cutting velocity, depth of cut, and other factors such as tool geometry, machining system stability, lubrication, and proper cutting tool selection, all play crucial roles [8]. Considering these many factors, it becomes very difficult to attain fine surface finish and high metal removal rate (MRR). The feed, cutting speed and the depth of cut are those parameters that can be controlled, and proper selection of these parameters yields proper surface finish to the MMCs [9].

The machining operations are classified under two important categories: cutting and grinding process. Process flexibility, yield time, high material removal rate and good surface finish are found to be salient features in the turning process. The proper prediction of cutting forces in the turning process is the primary task to achieve along with high dimensional accuracy and suitable machining system stability [10]. In the industry, metal removing processes are used to get the desired shape and dimension with precise quality. The process that removes metal at a higher rate and power consumed is considered to obtain an economical process [11]. Measuring the power consumption in the metal-removal-bycutting-tool operation helps for designing machine components, increasing the life of the tool for high productivity, and managing the capacity required by the motor for machine. The objective of the research is to analyze the percentage contribution of machining parameters like feed, cutting velocity, and the depth of cut of the developed MMC on surface roughness, material removal rate, and power consumed using RSM.

\section{EXPERIMENTAL DETAILS}

\subsection{Fabrication of MWCNT-Si-Al Matrix of 1 wt.\% by Stir Casting Method}

The Al-6065 ingot-castings were placed in the electric furnace and the temperature of the crucible in the furnace was raised and maintained at a temperature of $750{ }^{\circ} \mathrm{C}$ for about 20 minutes. This process was carried out to convert the material into a molten state. The 
molten metal was stirred continuously for about 15 minutes. The CNT powder was slowly added into the molten metal.

The stirring created a uniform mixture of the reinforced particle of $1 \mathrm{wt} . \%$ of MWCNT and $4 \%$ of silicon into molten mix. The molten metal was poured into the metal die and left for solidification. The sample of the specimen was considered for further machining processes [12].

\subsection{Turning Machine and the Cutting Conditions}

The experiments were conducted on a heavy-duty precision lathe machine as shown in Fig. 1, with a tungsten carbide tool. The cutter being the single point cutting tool, fed right into the rotating workpiece and cut the material as chips. This process was carried out to create the desired shape.

A full bridge strain gauge dynamometer was used to measure the cutting forces. This analog device is highly capable of measuring the cutting force while the turning operations are executed. This data of measured cutting force was utilized for further analysis [13]. The specimen of $\varnothing 25 \mathrm{~mm} \times \varnothing 75 \mathrm{~mm}$ size were used for the experimentation.

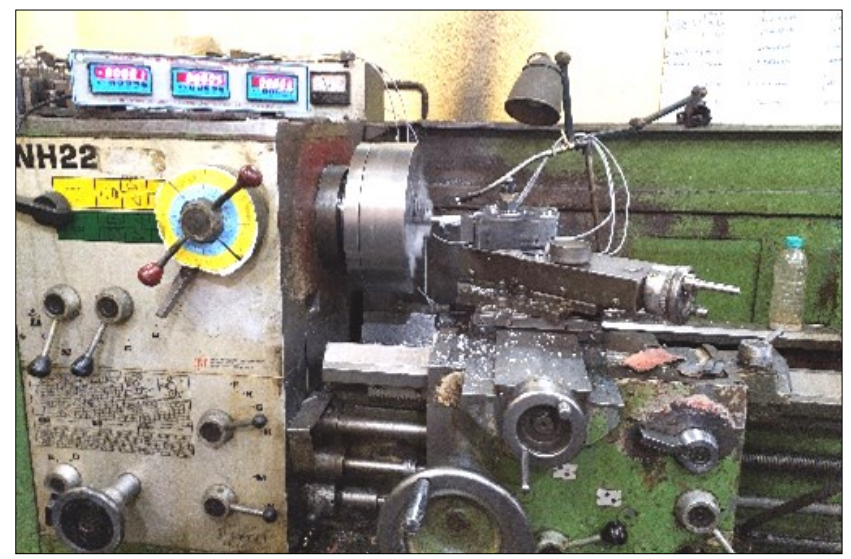

Fig. 1: Heavy-duty precision lathe machine.

\subsection{Design of Experiment (DoE) by Response Surface Methodology (RSM)}

A group of statistical and mathematical techniques that helps in modelling and analysis of a problem is termed as RSM. The output or the response of it can be controlled and is affected by several input variables. The objective here is to determine the correlation between the responses and variables determined.

RSM is one of several DoE methods, which is efficient for analyzing and planning the problem when certain independent variables will influence the dependent variables or when several obtained responses should yield valid and objective conclusions. Rotatable central composite design (CCD) and Box-Behnken design are the widely used and suitable types of RSM methods that are readily available for investigation purposes [14]. The embedded factorial design is not found in the Box-Behnken design and is an independent quadratic model. This design is normally incorporated while executing the non-sequential investigations. The design uses certain combinations for the treatment at the corners of the face center, the process space and at the center of the design body. The design requires three levels of each factor that are near to rotatable.

As compared to the CCD methods, the Box-Behnken model has less capability for the orthogonal blocking [15]. Thus, CCD methodology is the most commonly used technique 
in case of the second-order response models. The CCD provides very few numbers of experiment and, with a rotatable feature, the optimal response can be obtained [16]. Experimental independent variables along with their coded levels for the central composite design (CCD) are represented in Table 1.

Table 1: Experimental independent variables and their coded levels

\begin{tabular}{cccc}
\hline Independent variable & \multicolumn{3}{c}{ Levels of variables } \\
\cline { 2 - 4 } & Low & Medium & High \\
\hline Cutting velocity $(\mathrm{m} / \mathrm{min})$ & 30 & 50 & 70 \\
Feed $(\mathrm{mm} / \mathrm{rev})$ & 0.2 & 0.3 & 0.4 \\
Depth of cut $(\mathrm{mm})$ & 0.5 & 0.85 & 1.2 \\
\hline
\end{tabular}

\subsection{Surface Roughness $\left(R_{a}\right)$ and Its Measurement}

$R_{a}$ is a subjective property that indicates surface roughness. It is measured in micrometers, and has a crucial characteristic that quantifies high frequency deviations from that of an ideal surface. $R_{a}$ is the arithmetic mean value. It is based on the mean of normal deviations from a nominal surface. It is generally specified over the "cut-off" length and is represented in Eq. (1).

$$
R_{a}=\frac{1}{n} \sum_{i=1}^{n} y_{i}
$$

where, $R_{a}$ is surface roughness,

$n$ is number of measurement points and

$y_{i}$ is surface deviation at measurement point of ' $i$ '.

From the observation, it is noted that the values obtained are affected by few factors and machining parameters. The commercially available surface profilometers feature a diamond stylus that travels over the workpiece surface to measure the surface roughness [17].

\subsection{Power Consumption $\left(P_{c}\right)$}

A dynamometer is a measuring device used to measure tangential force from which power consumed by the machine can be calculated. The product of tangential force and the cutting velocity results in cutting power consumption $\left(P_{c}\right)$. It is represented by Eq. (2). The experiments were conducted using CCD by RSM [18].

$$
P=F_{z} \times v
$$

where, $P$ is power in kilowatts,

$F_{z}$ is force in newton and

$v$ is cutting speed in meter per second.

\subsection{Metal Removal Rate (MRR)}

The metal that is removed per unit time is the MRR. The SI unit of MRR is $\mathrm{mm}^{3} \mathrm{sec}^{-1}$. For every revolution associated with the material, a ring-shaped chip of the material is taken out. The MRR can be obtained using Eq. (3).

$$
M R R=v \times f \times d
$$

where, $v$ is the cutting velocity in $\mathrm{m} / \mathrm{min}$,

$f$ is the feed in $\mathrm{mm} / \mathrm{rev}$, and

$d$ is the depth of cut in $\mathrm{mm}$. 


\section{RESULTS AND DISCUSSION}

\subsection{Validation for Surface Roughness by Response Surface Methodology}

The experiments were executed according to $\mathrm{CCD}$, that was generated by response surface methodology (RSM) with three input variables: cutting speed (v), feed (f) and depth of cut (d). Twenty experimental runs were executed with $95 \%$ confidence level. The readings of trial runs were measured for the surface roughness using the surface roughness tester measuring machine and the cutting force using the lathe tool dynamometer. The response output obtained for MRR, experimental $R_{a}$, model $R_{a}$, and \% of error is tabulated in Table 2. Regression coefficients obtained from the experimental results are shown in Table 3 for polynomial regression equation of surface roughness $\left(R_{a}\right)$. Table 4 shows the corresponding analysis of variance and is obtained using Minitab-14 software.

Table 2: Experimental runs and surface roughness responses

\begin{tabular}{ccccccccc}
\hline $\begin{array}{c}\text { SI. } \\
\text { No }\end{array}$ & \multicolumn{3}{c}{ Input Variables } & \multicolumn{5}{c}{ Output Responses } \\
& $\begin{array}{c}\text { Cutting } \\
\text { velocity }(\boldsymbol{v})\end{array}$ & $\begin{array}{c}\text { Feed } \\
(\boldsymbol{f})\end{array}$ & $\begin{array}{c}\text { Depth of cut } \\
(\boldsymbol{d})\end{array}$ & $\begin{array}{c}\text { MRR } \\
\left(\mathbf{m m}^{\mathbf{3}} \mathbf{~ m i n}^{-\mathbf{1}}\right)\end{array}$ & $\begin{array}{c}\text { Exp. } \\
(\boldsymbol{R} \boldsymbol{a})\end{array}$ & $\begin{array}{c}\text { Model } \\
(\boldsymbol{R} \boldsymbol{a})\end{array}$ & $\begin{array}{c}\boldsymbol{R}_{\boldsymbol{a}} \\
(\mathbf{D i f f})\end{array}$ & $\begin{array}{c}\text { \% } \\
\text { Error }\end{array}$ \\
\hline 1 & 30 & 0.2 & 1.20 & 120.000 & 1.34 & 1.360 & 0.020 & 1.559 \\
2 & 70 & 0.2 & 0.50 & 116.667 & 1.68 & 1.865 & 0.185 & 11.058 \\
3 & 30 & 0.4 & 0.50 & 100.000 & 2.8 & 3.023 & 0.223 & 7.977 \\
4 & 70 & 0.4 & 0.50 & 233.333 & 3.12 & 3.324 & 0.204 & 6.543 \\
5 & 30 & 0.4 & 1.20 & 240.000 & 3.1 & 3.138 & 0.038 & 1.254 \\
6 & 30 & 0.2 & 0.50 & 50.000 & 1.93 & 1.935 & 0.005 & 0.278 \\
7 & 70 & 0.2 & 1.20 & 280.000 & 0.96 & 0.960 & 0.0008 & 0.093 \\
8 & 50 & 0.3 & 0.85 & 212.500 & 3.86 & 3.918 & 0.058 & 1.527 \\
9 & 50 & 0.3 & 0.85 & 212.500 & 3.91 & 3.918 & 0.008 & 0.229 \\
10 & 50 & 0.3 & 0.85 & 212.500 & 3.87 & 3.918 & 0.048 & 1.265 \\
11 & 70 & 0.4 & 1.20 & 560.000 & 2.89 & 3.109 & 0.219 & 7.587 \\
12 & 50 & 0.3 & 0.85 & 212.500 & 3.84 & 3.918 & 0.078 & 2.056 \\
13 & 17.34 & 0.3 & 0.85 & 73.695 & 2.86 & 2.786 & 0.073 & 2.583 \\
14 & 50 & 0.4633 & 0.85 & 328.171 & 3.64 & 3.391 & 0.248 & 6.830 \\
15 & 50 & 0.3 & 0.85 & 212.500 & 3.91 & 3.918 & 0.008 & 0.229 \\
16 & 82.66 & 0.3 & 0.85 & 351.305 & 2.82 & 2.705 & 0.114 & 4.073 \\
17 & 50 & 0.3 & 1.42155 & 355.388 & 2.41 & 2.407 & 0.002 & 0.088 \\
18 & 50 & 0.3 & 0.27845 & 69.613 & 3.26 & 3.052 & 0.207 & 6.368 \\
19 & 50 & 0.3 & 0.85 & 212.500 & 3.9 & 3.918 & 0.018 & 0.486 \\
20 & 50 & 0.1367 & 0.85 & 96.829 & 0.71 & 0.748 & 0.038 & 5.472 \\
\hline
\end{tabular}

Table 3: Estimated regression coefficients for $R_{a}$ in $\mu \mathrm{m}$

\begin{tabular}{ccccc}
\hline Term & Coeff. & SE Coeff. & T & P \\
\hline Constant & -8.1365 & 0.95560 & -8.514 & 0.000 \\
$\boldsymbol{v}$ & 0.1049 & 0.01682 & 6.237 & 0.000 \\
$\boldsymbol{f}$ & 43.1855 & 3.57327 & 12.086 & 0.000 \\
$\boldsymbol{d}$ & 4.7344 & 0.95350 & 4.965 & 0.001 \\
$\boldsymbol{v}^{2}$ & -0.0011 & 0.00012 & -9.384 & 0.000 \\
$\boldsymbol{f}^{2}$ & -69.3314 & 4.73106 & -14.655 & 0.000 \\
$\boldsymbol{d}^{2}$ & -3.6393 & 0.38621 & -9.423 & 0.000 \\
$\boldsymbol{v} \mathrm{X} \boldsymbol{f}$ & 0.0463 & 0.03039 & 1.522 & 0.159 \\
$\boldsymbol{v} \mathrm{X} \boldsymbol{d}$ & -0.0118 & 0.00868 & -1.357 & 0.205 \\
$\boldsymbol{f} \mathrm{X} \boldsymbol{d}$ & 4.9286 & 1.73676 & 2.838 & 0.018 \\
\hline $\mathrm{S}=0.171930$ & $\mathrm{R}^{2}=98.53 \%$ & $\mathrm{R}^{2}$ (pred.) $=88.95 \%$ & $\mathrm{R}^{2}$ (adj.) $=97.21 \%$ \\
\hline
\end{tabular}


Table 4: Analysis of variance for $R_{a}$ in $\mu \mathrm{m}$

\begin{tabular}{ccccccc}
\hline Source & DF & Seq SS & Adj SS & Adj MS & F & P \\
\hline Regression & 9 & 19.8663 & 19.8663 & 2.20737 & 74.67 & 0.000 \\
Linear & 3 & 9.2669 & 4.6496 & 1.54985 & 52.43 & 0.000 \\
Interaction & 3 & 10.2385 & 10.2385 & 3.41282 & 115.45 & 0.000 \\
Square & 3 & 0.3610 & 0.3610 & 0.12032 & 4.07 & 0.040 \\
Residual Error & 10 & 0.956 & 0.2956 & 0.02956 & & \\
Lack-of-Fit & 5 & 0.2913 & 0.2913 & 0.05826 & 68.01 & 0.000 \\
Pure Error & 5 & 0.0043 & 0.0043 & 0.00086 & & \\
$\quad$ Total & 19 & 20.1619 & & & & \\
\hline
\end{tabular}

The model developed was investigated using the analysis of variance technique. The value of the determination coefficient $\left(R^{2}=95.00 \%\right)$ specified that only the values that are less than the $5 \%$ of total variations were not explained by the developed model and this indicated the quality of the model's fit. The value of the adjusted determination coefficient (adj. $R^{2}=0.9500$ ) was high and specifies that the obtained model was highly significant. If $\mathrm{P}$-value is less than F-value $(\mathrm{P}<\mathrm{F})$, it indicates that the model is highly significant. The results of $R_{a}$ as obtained using ANOVA is represented in Table 4. It describes the predictability of the obtained model for its surface roughness $\left(R_{a}\right)$ to be at a $99 \%$ confidence level. This is due to the average value of ' $\mathrm{P}$ ' which is less than 0.0001 . Figure 2 shows that the experimental output, surface roughness $\left(R_{a}\right)$ is closer to the regression model obtained using RSM method. The $R^{2}$ was found to be $98.53 \%$ and shows that the regression equation is highly reliable [21]. The lower value of ' $\mathrm{P}=0.01$ ' indicates the statistic significance of the model and concludes that the proposed model is a correct one.

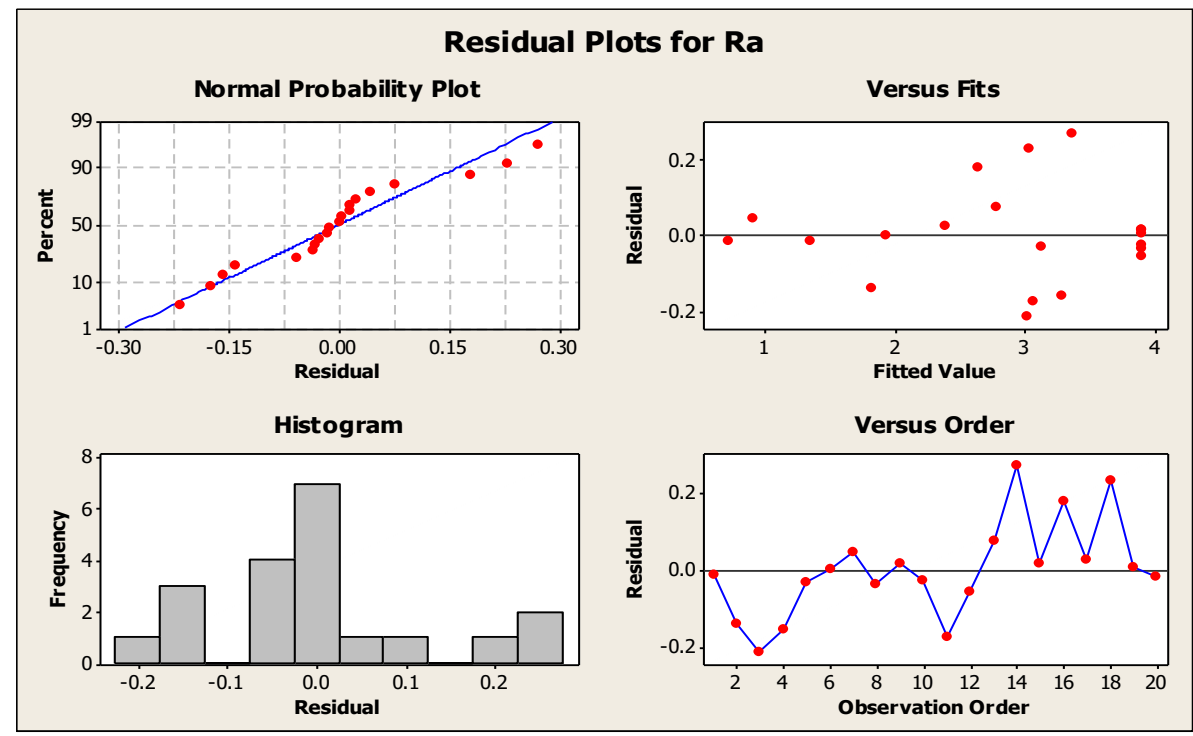

Fig. 2: Residual plots for $R_{a}$ in $\mu \mathrm{m}$.

Residual plots for $R_{a}$ shown in Fig. 2 have been analyzed and are discussed. The probability plot was used to check for the data normality. The distribution of the data points all along the normal line with very few outliers indicated that the data is normally distributed. The residual versus fitted values, as shown in the second plot, do not show any subsequent trends. This indicates the chosen RSM model fits well within the given dataset. The third plot of frequency verses residual illustrates the normal distribution of residuals that are produced by the model and assures that the assumptions made are reasonable and the choice of the model is appropriate. The residue verses observation order as depicted in the last plot 
highlights the presence of random data points. The randomness in the plot shows the insignificant experimental order in comparison to first surface response $\left(R_{a}\right)$. A confidence level of $95 \%$ has been applied to RSM for $R_{a}$. The statistical significance of the surface roughness has been measured and concluded based on all the factors and respective interactions which has a probability value or P-Value to be less than 0.05 .

\subsection{Optimized Solution for Surface Roughness}

The lower values, the upper values and the final target values of $R_{a}$ responses are fed to the response optimizer tool of Minitab by giving equal weightages. The description of the same is given in Table 5 .

Table 5: Response optimization

\begin{tabular}{cccccc}
\hline Goal & Lower & Target & Upper & Weight & Import \\
\hline Optimization of $\boldsymbol{R}_{\boldsymbol{a}}$ & 0.71 & 1.1 & 3.91 & 1 & 1 \\
\hline
\end{tabular}

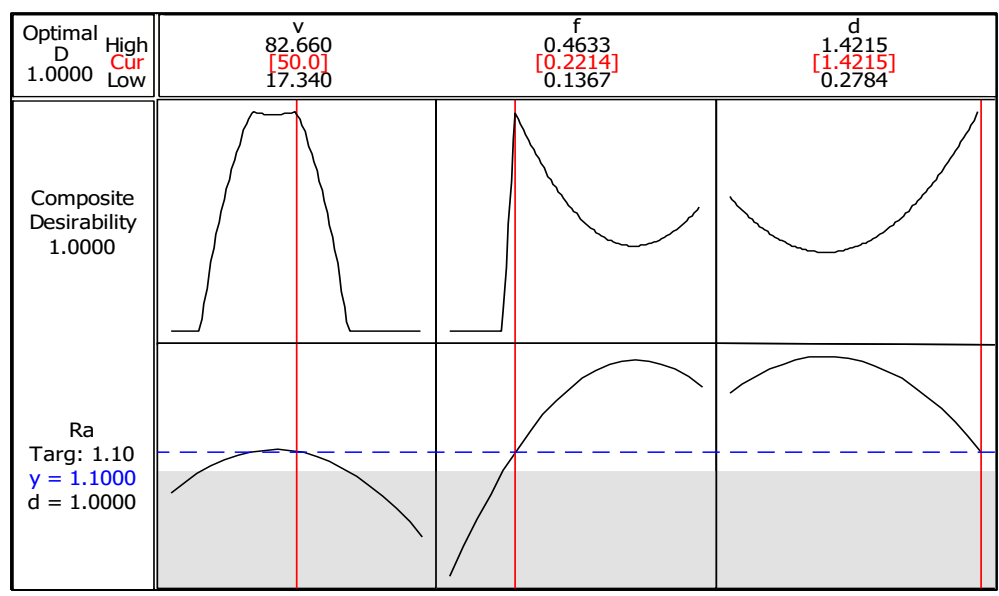

Fig. 3: Predicted response for $R_{a}$ in $\mu \mathrm{m}$.

A significant solution of about $100 \%$ composite desirability is provided by the software. This is concluded from the analysis of data of experiments. About $50 \mathrm{~m} / \mathrm{min}$ cutting velocity, $0.2214 \mathrm{~mm} / \mathrm{rev}$ of feed rate, and $1.4215 \mathrm{~mm}$ of DOC along with $1.1 \mu \mathrm{m}$ of minimum surface roughness is reached. Lower half of Fig. 3 shows the of variation of $R a$ along with focused input variables. The blue dotted lines indicate the pin-pointing desired optimal points [19].

\subsection{Validation for Power consumption by RSM}

The experiments were conducted using three input variables such as cutting speed $(v)$, feed rate $(f)$, depth of cut $(d)$ for 20 experimental run and obtain the output responses as cutting forces $\left(F_{z}\right)$ in $\mathrm{z}$ direction, power consumption $\left(P_{c}\right)$, difference of power consumption and percentage error are shown in the Table 6 . The output of the experiments was measured using tool dynamometer for cutting forces and calculated the power consumption. Regression coefficients are as shown in Table 7 for polynomial regression equation of power consumption $\left(P_{c}\right)$ and Table 8 shows the corresponding analysis of the variance.

The ANOVA results of the $P_{c}$ is shown in Table 8 . It indicates the obtained model for the surface roughness having probability of $99 \%$ confidence level. This is due to the average value of $\mathrm{P}$-value, which is less than 0.0001 . The $R^{2}$ is $99.40 \%$ and provides a highly reliable regression equation [21]. 
Table 6: Experimental run and power consumption results

\begin{tabular}{ccccccccr}
\hline SI. & \multicolumn{2}{c}{ Input Parameters } & \multicolumn{5}{c}{ Output Responses } \\
\cline { 2 - 8 } No & $\begin{array}{c}\text { Cutting } \\
\text { velocity }(\boldsymbol{v})\end{array}$ & $\begin{array}{c}\text { Feed } \\
(\boldsymbol{f})\end{array}$ & $\begin{array}{c}\text { Depth of } \\
\text { cut }(\boldsymbol{d})\end{array}$ & $\boldsymbol{F}_{\boldsymbol{z}}(\mathbf{i n} \mathbf{N})$ & $\begin{array}{c}\boldsymbol{P}_{\boldsymbol{c}} \\
\text { (in W) }\end{array}$ & $\begin{array}{c}\mathbf{Y} \\
\left(\boldsymbol{P}_{\boldsymbol{c}} \text { ) }\right.\end{array}$ & $\begin{array}{c}\boldsymbol{P}_{\boldsymbol{c} .} \\
\text { (Diference) }\end{array}$ & \% Error \\
\hline 1 & 30 & 0.2 & 1.2 & 107.910 & 53.955 & 51.12824 & 2.82676 & 5.239107 \\
2 & 70 & 0.2 & 0.5 & 49.050 & 57.225 & 55.38798 & 1.83702 & 3.21017 \\
3 & 30 & 0.4 & 0.5 & 78.480 & 39.240 & 38.20172 & 1.03828 & 2.645973 \\
4 & 70 & 0.4 & 0.5 & 88.290 & 103.005 & 107.0857 & 4.08072 & 3.961672 \\
5 & 30 & 0.4 & 1.2 & 166.770 & 83.385 & 86.47904 & 3.09404 & 3.710547 \\
6 & 30 & 0.2 & 0.5 & 49.050 & 24.525 & 27.37598 & 2.85098 & 11.62479 \\
7 & 70 & 0.2 & 1.2 & 117.720 & 137.340 & 139.6482 & 2.30824 & 1.680676 \\
8 & 50 & 0.3 & 0.85 & 127.530 & 106.275 & 105.5303 & 0.74475 & 0.700776 \\
9 & 50 & 0.3 & 0.85 & 137.340 & 114.450 & 105.5303 & 8.91975 & 7.793578 \\
10 & 50 & 0.3 & 0.85 & 127.530 & 106.275 & 105.5303 & 0.74475 & 0.700776 \\
11 & 70 & 0.4 & 1.2 & 186.390 & 217.455 & 215.871 & 1.58396 & 0.728408 \\
12 & 50 & 0.3 & 0.85 & 127.530 & 106.275 & 105.5303 & 0.74475 & 0.700776 \\
13 & 17.34 & 0.3 & 0.85 & 137.340 & 39.691 & 39.13672 & 0.5545442 & 1.397144 \\
14 & 50 & 0.4633 & 0.85 & 147.150 & 122.625 & 117.5362 & 5.088793954 & 4.149883 \\
15 & 50 & 0.3 & 0.85 & 117.720 & 98.100 & 105.5303 & 7.43025 & 7.574159 \\
16 & 82.66 & 0.3 & 0.85 & 127.530 & 175.694 & 167.6571 & 8.0367482 & 4.574292 \\
17 & 50 & 0.3 & 1.42155 & 176.580 & 147.150 & 144.282 & 2.868011577 & 1.949039 \\
18 & 50 & 0.3 & 0.27845 & 49.050 & 40.875 & 36.06505 & 4.809945647 & 11.76745 \\
19 & 50 & 0.3 & 0.85 & 127.530 & 106.275 & 105.5303 & 0.74475 & 0.700776 \\
20 & 50 & 0.1367 & 0.85 & 58.860 & 49.050 & 46.46107 & 2.588926864 & 5.278138 \\
\hline
\end{tabular}

Residual Plots for $P_{c}$ shown in Fig. 4 has been analyzed and is discussed. The probability plot is used to check for the data normality. The distribution of the data points all along the normal line with very few outliers indicates that the data is normally distributed. The residual versus fitted values, as shown in the second plot, do not show any subsequent trends. This indicates the chosen RSM model fits well within the given dataset. The third plot of frequency verses residual illustrates the normal distribution of residuals that are produced by the model and assures that the assumptions made are reasonable and the choice of the model is appropriate. The residue versus observation order, as depicted in the last plot, highlights the presence of random data points. The randomness in the plot shows an insignificant experimental order in comparison to first power consumption $\left(P_{c}\right)$. A confidence level of $95 \%$ has been applied to RSM for $P_{c}$.

Table 7: Estimated regression coefficients for $P_{c}$ in watts

\begin{tabular}{ccccc}
\hline Term & Coeff. & SE Coeff. & T & P \\
\hline Constant & -43.838 & 29.576 & -1.482 & 0.169 \\
$\boldsymbol{v}$ & -1.202 & 0.521 & -2.308 & 0.044 \\
$\boldsymbol{f}$ & 342.726 & 110.593 & 3.099 & 0.011 \\
$\boldsymbol{d}$ & 13.983 & 29.511 & 0.474 & 0.646 \\
$\boldsymbol{v}^{2}$ & -0.002 & 0.004 & -0.429 & 0.677 \\
$\boldsymbol{f}^{2}$ & -882.428 & 146.426 & -6.026 & 0.000 \\
$\boldsymbol{d}^{2}$ & -47.010 & 11.953 & -3.933 & 0.003 \\
$\boldsymbol{v} \mathbf{x} \boldsymbol{f}$ & 5.109 & 0.941 & 5.432 & 0.000 \\
$\boldsymbol{v} \mathbf{x} \boldsymbol{d}$ & 2.161 & 0.269 & 8.039 & 0.000 \\
$\boldsymbol{f} \mathbf{x} \boldsymbol{d}$ & 175.179 & 53.753 & 3.259 & 0.009 \\
\hline $\mathrm{S}=5.32124$ & $R^{2}=99.40 \%$ & $R^{2}$ (pred.) $=97.00 \%$ & $R^{2}(\operatorname{adj})=.98.86 \%$ \\
\hline
\end{tabular}


Table 8: Analysis of variance for $P_{c}$ in watts

\begin{tabular}{ccccccc}
\hline Source & DF & Seq. SS & Adj. SS & Adj. MS & F & P \\
\hline Regression & 9 & 46840.3 & 46840.3 & 5204.47 & 183.80 & 0.000 \\
Linear & 3 & 42495.3 & 575.7 & 191.90 & 6.78 & 0.009 \\
Interaction & 3 & 1379.0 & 1379.0 & 459.68 & 16.23 & 0.000 \\
Square & 3 & 2965.9 & 2965.9 & 988.65 & 34.92 & 0.000 \\
Residual Error & 10 & 283.2 & 283.2 & 28.32 & & \\
Lack-of-Fit & 5 & 149.5 & 149.5 & 29.90 & 1.12 & 0.453 \\
Pure Error & 5 & 133.7 & 133.7 & 26.73 & & \\
$\quad$ Total & 19 & 47123.4 & & & & \\
\hline
\end{tabular}

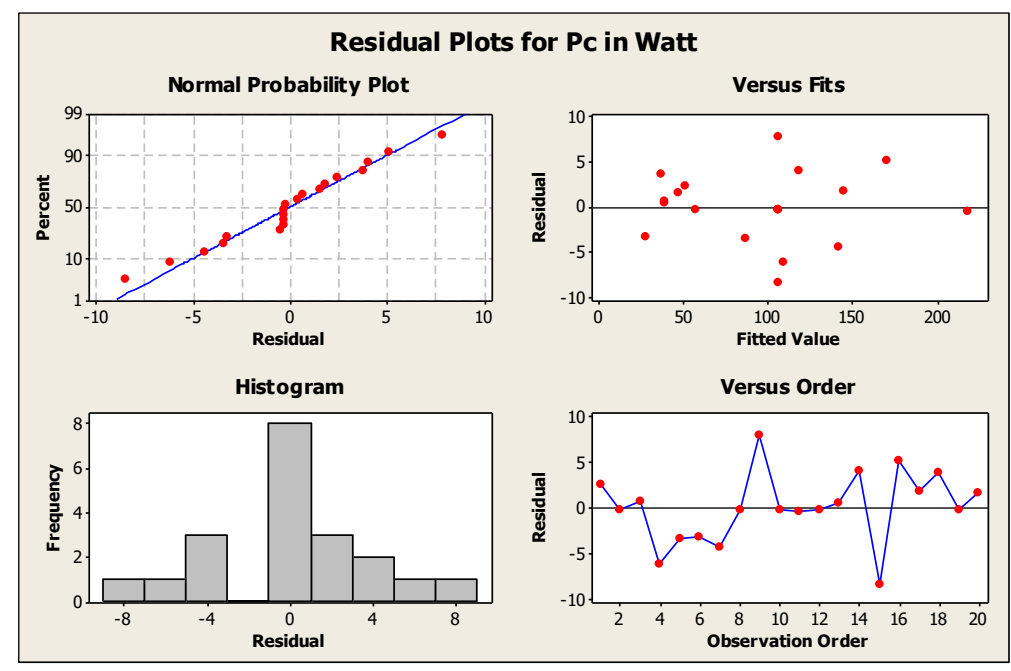

Fig. 4: Residual plots for $P_{c}$ in watts.

\subsection{Optimized Solution for Power Consumption}

The lower values, the upper values and the final target values of $P_{c}$ responses are fed to the response optimizer tool of Minitab by giving equal weightages. The description of the same is given in Table 9.

Table 9: Response optimization for power consumption

\begin{tabular}{cccccc}
\hline Goal & Lower & Target & Upper & Weight & Import \\
\hline Optimization of $\boldsymbol{P}_{\boldsymbol{c}}$ & 24.525 & 40 & 217.455 & 1 & 1 \\
\hline
\end{tabular}

\begin{tabular}{|c|c|c|c|}
\hline $\begin{array}{l}\text { Optimal } \\
\text { Digh } \\
1.0000 \text { Cow }\end{array}$ & $\begin{array}{c}82.660 \\
{[17.3407} \\
17.340\end{array}$ & $\begin{array}{c}0.4633] \\
{\left[\begin{array}{l}0.43132] \\
0.1367\end{array}\right.} \\
\end{array}$ & $\begin{array}{c}1.4215 \\
{\left[\begin{array}{c}1 \\
1 \\
0.4215] \\
0.2784\end{array}\right]}\end{array}$ \\
\hline $\begin{array}{c}\text { Composite } \\
\text { Desirability } \\
1.0000\end{array}$ & & & \\
\hline $\begin{array}{l}\text { Pc in wa } \\
\text { Targ: } 40.0 \\
\text { y= 40.0000 } \\
d=1.0000\end{array}$ & & & \\
\hline & & & \\
\hline
\end{tabular}

Fig. 5: Predicted response for $R_{a}$ in $\mu \mathrm{m}$. 
Minimum power consumption $\left(P_{c}\right)$ of 40 watts is obtained for a cutting velocity of $17.3407 \mathrm{~m} / \mathrm{min}$, feed rate of $0.3172 \mathrm{~mm} / \mathrm{rev}$ and depth of cut of $1.4215 \mathrm{~mm}$, as shown in the Fig. 5. The lower half of Fig. 5 shows the of variation of $P_{c}$ along with focused input variables [19].

\subsection{Development of Empirical Models}

The relation between the input machining parameters and the output responses is developed by the mathematical models and thereby optimization of the machining process. RSM is an optimization procedure that produces a multi objective function model which can solve the optimization problem. The present study concentrates on the development of Empirical models for the output responses, Surface roughness $\left(R_{a}\right)$ and power consumption $\left(P_{c}\right)$ with regards to the input machining parameters in actual factors by using RSM. [20]. Any further optimization of the machining process can be carried out using the developed models. The second order regression equations of the model that was developed are estimated by regression analysis. The following equations for $R_{a}$ and $P_{c}$ were obtained in terms of actual factors.

The polynomial optimization equation of surface roughness $\left(R_{a}\right)$ :

$\boldsymbol{R}_{a}=-8.1365+(0.1049 \times v)+(43.1855 \times f)+(4.7344 \times d)-\left(0.0011 \times v^{2}\right)-$ $\left(69.3314 \times f^{2}\right)-\left(3.6393 d^{2}\right)+(0.0463 \times v \times f)-(0.0118 \times v \times d)+(4.9286 \times f \times$ d)

The polynomial optimization equation of power consumption $\left(P_{c}\right)$ :

$\boldsymbol{P}_{c}=(-11.189)-(0.052 \times v)+(70.789 \times f)+(14 \times d)-\left(0.000 \times v^{2}\right)-$ $\left(115.384 \times f^{2}\right)-\left(6.358 \times d^{2}\right)+(0.125 \times v \times f)+(0.036 \times v \times d)+(21.429 \times f \times d)$

\section{CONCLUSION}

This study presents an effective method for estimating the optimal turning operation parameters for surface roughness and power consumption using response surface methodology. The investigation shows that the control factors had varying effects on the response variable. The use of central composite design of response surface methodology was considered successful to obtain optimal responses. The results of power consumption $\left(P_{c}\right)$ as obtained using ANOVA is represented in Table 8. The average value of ' $\mathrm{P}$ ' was less than 0.001 and hence the model obtained for power consumption to be at a $99 \%$ confidence level. Fig. 4 shows that the output response is closer to the regression model obtained using RSM method. The surface roughness was mainly affected by the feed and the cutting speed. Also, an increase in the feed rate resulted in higher surface roughness. It was also observed that the cutting speed varies inversely along with surface roughness, thereby increasing the surface finish of the workpiece. The observed ANOVA response of the cutting velocity and depth of cut majorly influenced the power consumed by the machine. Minimum surface roughness along with minimum power consumption was estimated using the optimized solution parameters. This demonstrates that the RSM can be successfully applied to obtain a maximum amount of information with the least number of experimental runs. This can be successfully implemented to obtain an effective second order polynomial and for optimizing the machining process.

\section{ACKNOWLEDGEMENTS}

The authors wish sincere thanks to Basheer Ahmed Mohamed, the Managing Director of Sidhi Vinayaka Fab Engineering Pvt. Ltd., Peenya Industrial Area, Bangalore, India, for providing us the research facilities and supporting us in handling the research work. 


\section{REFERENCES}

[1] Esawai A, Morsi K. (2007) Dispersion of carbon nanotubes (CNTs) in aluminium powder Composites part-A Applied Science and Manufacturing, 38: 646-650.

[2] Iijima S. (1991) Helical microtubules of graphic carbon. Nature, 354: 56-58.

[3] Bakshi SR, Lahiri D, Agarwal A. (2010) Carbon nanotube reinforced metal matrix composites - A review. International Materials Reviews, 55: 41-64.

[4] Liu ZY, Yu SJ, Xiao BL. (2012) Effect of ball milling time on mechanical properties of carbon nanotubes reinforced aluminium matrix composites. Composites part-A applied Zcience and Manufacturing, 43: 2161-2168.

[5] Baburaj E, Senthil P, Dhanapal P. (2018) Investigation on influence of machining parameters on high speed phase milling of hybrid (LM0-SiC-Fly Ash). Composite Int J Pure and Appl Math, 118(20): 901-906.

[6] Stratford KN, Audy J. (1997) Indirect monitoring of machinability in carbon steels by measurement of cutting forces. J. Mater Processing Tech, 67(1-3): 150-156.

[7] Teti R. (2002) Machining of composite materials. CIRP Annals, 51(2): 611-634.

[8] Ranganath MS, Vipin RSM. (2014) Effect of cutting parameters on MRR and surface roughness in turning of Aluminium-6061. Int J Adv Res and Innov, 2(1): 32-39.

[9] Parhad P, Likhite A, Bhatt J. (2015) The effect of cutting speed and depth of cut on surface roughness during machining of austempered ductile iron. Transactions of the Indian Institute of Metals, 68: 99-108. https://doi.org/10.1007/s12666-014-0439-y.

[10] Thangarasu SK, Shankar S, Thomas AT, Sridhar G. (2018) Prediction of cutting force in turning Process-an experimental approach, IConAMMA-2017, IOP Conf. Series: Materials Science and Engineering, 310: 012119.

[11] Patel MT, Deshpande VA. (2014) Optimization of machining parameters for turning different alloy steel using CNC-Review. Int J Innov Res Sci Eng Tech, 3(2): 2319-8753.

[12] Puttaswamy SJ, Venkatagiriyappa RB. (2020) Investigation on influence of anionic surfactant for homogenisation of MWCNT in Aluminium 6065 matrix. IIUM Engineering Journal, 21(2). https://doi.org/10.31436/iiumej.v21i2.1317

[13] Thangarasu SK. (2018) Prediction of cutting force in turning process-an experimental approach. IOP Conference Series: Materials Science and Engineering, 310: 012119.

[14] Samuel MK, Chandrasekaran C, Paarthasarathy B, Kamalakkannan SD. (2013) Prediction of surface roughness response in turning on $\mathrm{Cu}$ graphite $\mathrm{MMC}$ fabricated through stir-casting method. IJETAE, IESSN 3(3): 2250-2459.

[15] Geo R, D'Cotha JS. (2014) Effect of turning parameters on power consumption in EN 24 alloy steel suing different cutting tools. Int J Eng Res Gen Sci, 2(6): 2091-2730.

[16] Akcay H, Anagun AS. (2013) Multi response optimization application on a manufacturing factory. Mathematical and Computational Application, 18(3): 531-538.

[17] Kuttolamadom M, Hamzehlouia S, Mears L. (2010) Effect of machining feed on surface roughness in cutting 6061 aluminum. SAE Int J Mater Manuf, 3(1): 108-119. https://doi.org/10.4271/2010-01-0218.

[18] Richard Geo, Jose Sheril D'cotha (2014) Effect of Turning Parameters on Power Consumption in EN 24 Alloy Steel using Different Cutting Tools, International Journal of Engineering Research and General Science, Vol. 2, Issue 6, October-November, ISSN 20912730.

[19] Singh BJ, Sodhi HS. (2014) Parametric optimisation of CNC turning for Al-7020 with RSM. Int J Operational Research, 20(2): 180-206.

[20] Ramudu C, Sastry MNP. (2012) Analysis and optimization of turning process parameters using design of experiments. Int J Eng Res Appl, 2(6): 20-27.

[21] Lakshminarayanan AK, Balasubramanian V. (2009) Comparison of RSM with ANN in predicting tensile strength of friction stir welded AA7039 aluminium alloy joints. Transactions of Nonferrous Metals Society of China, 19(1): 9-18. 